\title{
Chromosomal Location of Lectin Genes Indicates They Are Not the Basis of Rhizobium Strain Specificity Mutations Identified in Pea (Pisum sativum L.)
}

\author{
J. Lu, N. F. Weeden, and T. A. LaRue
}

\begin{abstract}
A lectin gene family is located on linkage group 7 in pea. The lectin genes are arranged as a cluster, with no recombination observed within the multigene family. A lectinlike cDNA clone, pEA207, and eight DNA fragments generated by random priming also were mapped in the region of the lectin genes. None of the known pea mutants altering Rhizobium leguminosarum strain specificity map to this region of the genome, and therefore their altered specificities appear not to be directly produced by mutations in the lectin genes.
\end{abstract}

Lectins are proteins that bind specific carbohydrates. In plants, these proteins occur in highest concentrations in seeds, but they also are present in roots and other tissues (Borrebaeck 1984; Buffard et al. 1988; Díaz et al. 1984; Vodkin and Raikhel 1986). The lectins present in roots are thought to be encoded by the same genes as those in seeds, although their sugar specificity might differ (Gatehouse and Boulter 1980). The differences in sugarbinding specificity are caused by posttranslational modification of the lectin (Kaminski et al. 1987; Okamura et al. 1986). Of the numerous functions lectins have in the plant, one of the most interesting is their role in cell recognition mechanisms. They have been implicated in pollen-pistil interaction (Heslop-Harrison 1976; Knox et al. 1976), in defense response, and as receptors for the attachment of pathogens (Etzler 1986).

We have been studying the genetic basis of nodule formation in pea (Pisum sativum L.) and have examined several natural and induced mutants with altered specificity for strains of Rhizobium leguminosarum (Kneen et al. 1987; Weeden et al. 1990). Diaz et al. (1989) demonstrated that lectins function as a determinant of host-plant specificity in the Rhizobium-legume symbiosis. Indeed, their experiment in which Trifolium repens gained the ability to be nodulated by $R$. leguminosarum biovar viciae after its roots were transformed with the pea lectin gene suggested that lectin was a key determinant of host-plant specificity. The altered strain specificity of the natural pea mutants, sym2 and sym22, as well as the induced mutants of sym 2 and sym 18 , thus may be produced by changes in the DNA sequence of the lectin gene. As lectins are known to be coded by multigene families in lentil (Lens culinaris) (Foriers et al. 1981), common bean (Phaseolus vulgaris) (Hoffman and Donaldson 1985), soybean (Glycine max) (Vodkin et al. 1983), and Medicago truncatula (Bauchrowitz et al. 1992), the distinct strain specificity mutants may represent mutations at different lectin sequences in pea. The purpose of this study was to map the lectin genes on the pea genome and compare their positions with those of the strain specificity mutants.

\section{Materials and Methods}

Mapping Lectin Genes and a Lectin-Like cDNA Clone

Twenty-seven $F_{2}$ individuals and $38 F_{7}$ inbred lines (derived by single seed descent of $\mathrm{F}_{2}$ individuals) from the cross of JI 1794 $\times$ Slow were used for mapping the lectin genes. JI 1794 is a $P$. sativum ssp. humile line obtained from the John Innes Institute, Norwich, England, and Slow is a $P$. $s$. ssp. sativum marker line developed at Geneva, New York. The two parental lines differed at 18 isozyme loci, 10 morphological loci, and 40 restriction fragment length polymorphisms. These loci were well distributed over the pea genome (Weeden and Wolko 1990; Weeden, unpublished observations). Isozyme, morphological, and lectin RFLP phenotypes were scored on $F_{2}$ or $F_{2}: F_{3}\left(F_{2}\right.$ derived $\left.F_{3}\right)$ plants and on the $F_{7}$ inbred lines.

For the $\mathrm{F}_{2}$ DNA analysis, we pooled five $F_{3}$ plants. For $F_{7}$ analysis, DNA was ex- 


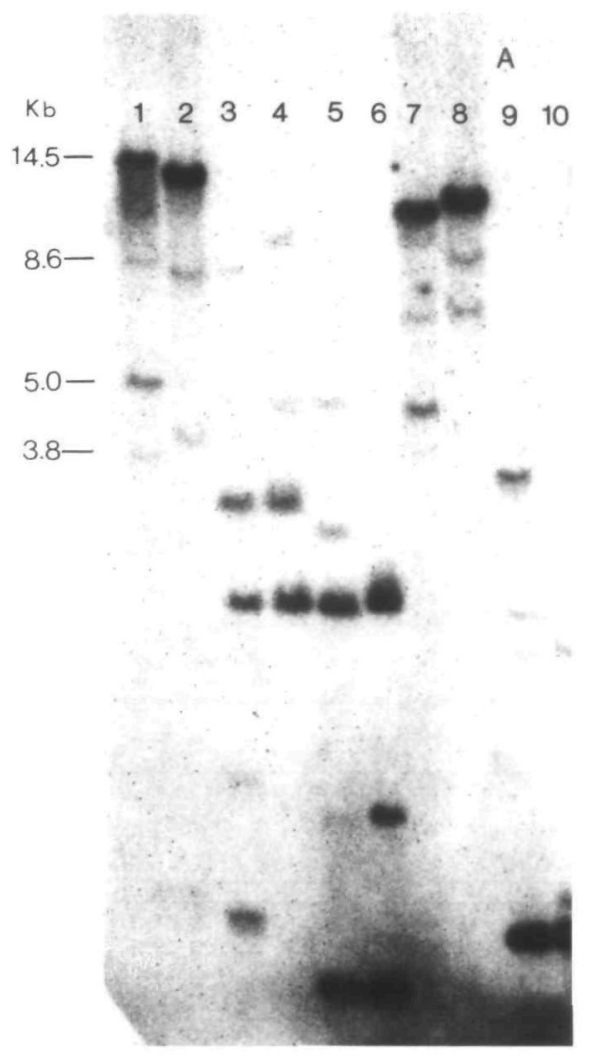

B

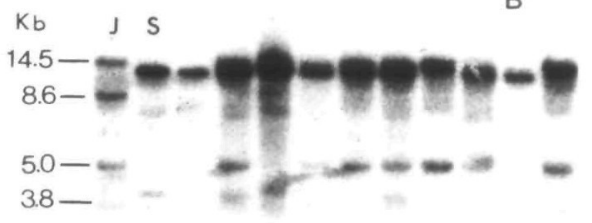

Figure 1. (A) Polymorphisms between the parents JI1794 (lanes 1, 3, 5, 7, and 9) and Slow (lanes 2, 4, 6, 8 , and 10$)$. Genomic DNA digested with different restriction enzymes and hybridized with labeled lectin cDNA PPS 15-50. Lanes 1 and $2=E c o R I$; lanes 3 and $4=E$ coRV; lanes 5 and $6=B a m H I$; lanes 7 and $8=$ HindIII; lanes 9 and $10=B c l$. (B) EcoRI phenotypes observed when lectin cDNA sequence pPS 15-50 was used as a hybridization probe on blots containing parental and combined $F_{3}$ DNA (to represent the $F_{2}$ generation). The two parental and an additional heterozygous phenotype were observed in the $F_{2}$. Relative band intensities in the heterozygous phenotype varied because five to $10 \mathrm{~F}_{3}$ plants were randomly chosen for the combined sample so that the ratio of genotypes in this sample often was skewed toward one of the parental types. $\mathrm{J}=\mathrm{J} 11794 ; \mathrm{S}=$ Slow.

tracted from one or more $F_{7}$ plants. We prepared DNA from young leaves according to the method of Doyle and Doyle (1987). Five restriction enzymes BamHI, $B c l l, E c o R I, E c o R V$, and HindIII were used to test restriction polymorphisms of the parental lines. EcoRI was chosen for the restriction digestion of the progenies because it was used in previous studies (Kaminski et al. 1986, 1987). Digested DNA was separated on $1 \%$ agarose gels. After electrophoresis, DNA was transferred to
Table 1. Single locus segregation and $\chi^{2}$ analysis for the lectin genes in an $F_{2}$ population from J11794 $\times$ Slow

\begin{tabular}{llllll} 
& \multicolumn{3}{l}{$\begin{array}{l}\text { Ratio in } \\
\text { progeny }\end{array}$} & & \\
\cline { 2 - 4 } Probe & Slow & Het. & JI1794 & $x^{2}$ & $P$ \\
\hline pPS 15-50 & 6 & 12 & 9 & 1.00 & .61 \\
pEA207 & 8 & 12 & 5 & 0.76 & .68
\end{tabular}

- Genotype designations: Slow = homozygous for allele in Slow parent; Het. = heterozygous; JII 794 = homozygous for allele in JI1794 parent.

nylon membranes (GeneScreen Plus, Du Pont) under alkaline conditions (Reed and Mann 1985).

The membranes were prehybridized in a bottle with $10 \mathrm{ml}$ of hybridization buffer at $65^{\circ} \mathrm{C}$ for $5 \mathrm{~h}$ in a Mini Hybridization Oven (National Labnet Company, NJ). The hybridization buffer consisted of $750 \mathrm{mM}$ $\mathrm{NaCl}, 175 \mathrm{mM}$ citric acid, $50 \mathrm{mM} \mathrm{NaPO}$, 2.5 mM EDTA, $5 \times$ Denhardt's, $5 \%$ dextran sulfate, $0.6 \% \mathrm{SDS}$, and $0.4 \mathrm{mg} / \mathrm{ml}$ calf thymus DNA. We used a pea lectin cDNA clone containing the entire pea lectin coding region, pPS15-50 (Higgins et al. 1983), and a pea lectin-like cDNA clone, pEA207 (Dobres and Thompson 1989), as probes. The probes were labeled by random priming (Feinberg and Vogelstein 1983). We performed hybridization at $65^{\circ} \mathrm{C}$ overnight. Membranes were washed at $65^{\circ} \mathrm{C}$ in (1) $2 \times \mathrm{SSC}, 0.1 \% \mathrm{SDS}$, (2) $1 \times \mathrm{SSC}, 0.05 \%$ SDS, and (3) $0.5 \times$ SSC, $0.05 \%$ SDS, for 30 min each.

\section{Mapping with RAPD Markers}

Thirty-eight $F_{7}$ recombinant inbred lines from the cross of JI1794 $\times$ Slow were used for the RAPD analysis. DNA for this analysis was extracted by the same method reported by Torres et al. (1993). For the PCR amplification, a sample with $25 \mu$ of reaction mixture contained: $2.5 \mu \mathrm{l} 10 \times$ buffer and 0.5 units of DNA Taq polymerase (Promega), $100 \mu \mathrm{M}$ dNTP, 20-25 ng genomic DNA, and $0.2-0.3 \mu \mathrm{M}$ primer. Seventy-three 10-mers were tested. Except for the requirements of $40 \%-70 \% \mathrm{GC}$ and absence of fold back symmetry, we chose the sequences of the primers arbitrarily. We performed amplification in a $\mathrm{COY}$ TempCycler (COY Corporation, Grass Lake, Michigan) programmed for 40 cycles of 1 $\min$ at $94^{\circ} \mathrm{C}, 2 \mathrm{~min}$ at $40^{\circ} \mathrm{C}$, and $2 \mathrm{~min}$ at $72^{\circ} \mathrm{C}$. Amplification products were resolved by electrophoresis with $2 \%$ agarose gel ( $1 \%$ normal molecular grade agarose plus $1 \%$ NuSieve GTG agarose, FMC). We scored segregation of markers from photographs of the ethidium bromide stained gel.

\section{Data Analysis}

LINKAGE-1 (Suiter et al. 1983) was used for linkage analysis, and MAPMAKER (Lander et al. 1987) was used for determining the sequence of markers. We calculated linkage relationships among lectin genes, cDNA pEA207, and isozyme loci from $F_{2}$ data only, although both $F_{2}$ and $F_{7}$ data were used to determine the order of these markers. The RAPDs were mapped from $F_{7}$ data only.

\section{Results}

Three to six bands were observed when endonuclease-digested DNA from either JI1794 or Slow were hybridized with the pea lectin cDNA, pPS15-50 (Figure 1A). Each of the five enzymes tested gave polymorphisms between the two parent lines. With EcoRI digestion, we identified four fragments, $14.5,8.6,5.0$, and $3.8 \mathrm{~kb}$, in the parent JI1794. In Slow, three EcoRI fragments were detected. Only three EcoRI patterns were observed in the $F_{2}$ : the two characteristic of each parent and a third displaying a codominant or heterozygous pattern (Figure 1B). These phenotypes gave a segregation ratio fitting the 1:2:1 ratio expected for a single locus (Table 1 ). Thus, if the multiple bands detected in this study represent a multigene family, this family appears to be clustered. Joint segregation analysis of the lectin phenotype with the marker loci placed the lectin gene family near the end of linkage group 7 , about 15 map units from Gal-2 (Table 2).

Probe pEA207 produced two to four bands, and these were usually polymorphic between the parental lines with each of the restriction enzymes used (Figure 2). None of the fragments detected by pEA207 matched any detected by pPS15-50. The two EcoRI polymorphisms revealed by pEA207 segregated as a single Mendelian locus and mapped to the same end of linkage group 7 as the lectin cluster, although pEA207 fragments mapped further from Gal-2 (Figure 3).

The 73 primers used in the RAPD analysis generated over 200 polymorphisms between the parents. Eight of the products, generated by seven different primers, mapped near the region where the lectin genes are located (Figure 3 ). Two products, one generated by primer $5^{\prime}$ AGTCGCTCAT and the other by $5^{\prime}$ CTCCAAGGCC, mapped within $10 \mathrm{cM}$ of the lectin cluster. The segregation pattern produced by the latter primer is shown in Figure 4. Thus, the RAPDs not only generated a finer resolution map of linkage 
Table 2. Jolnt $F_{2}$ segregation analysis involving lectin gene, pEA207, and associated isozyme locl

\begin{tabular}{|c|c|c|c|c|c|c|c|c|c|c|c|}
\hline \multirow[b]{2}{*}{ Loci } & \multicolumn{9}{|c|}{$\begin{array}{l}\text { No. of } F_{2} \text { plants with } \\
\text { designated genotype }\end{array}$} & \multirow[b]{2}{*}{$x^{2}$} & \multirow{2}{*}{$\begin{array}{l}\text { Recombi- } \\
\text { nation } \\
\text { fraction }\end{array}$} \\
\hline & $\mathrm{j} / \mathrm{j}$ & $\mathrm{j} / \mathrm{h}$ & $\mathrm{j} / \mathrm{s}$ & $h / j$ & $h / h$ & $\mathrm{~h} / \mathrm{s}$ & $s / j$ & $\mathrm{~s} / \mathrm{h}$ & $\mathrm{s} / \mathrm{s}$ & & \\
\hline Skdh/Est-2 & 1 & 1 & 0 & 1 & 14 & 0 & 0 & 0 & 6 & 27.3 & $0.04 \pm 0.03$ \\
\hline Skdh/Aat-m & 3 & 0 & 1 & 3 & 12 & 1 & 0 & 2 & 5 & 19.1 & $0.16 \pm 0.06$ \\
\hline Lectin/Aat-m & 4 & 4 & 1 & 1 & 8 & 2 & 1 & 2 & 4 & 8.5 & $0.28 \pm 0.07$ \\
\hline Lectin/Amyl & 5 & 3 & 1 & $i$ & 8 & 2 & 0 & 2 & 5 & 14.9 & $0.20 \pm 0.06$ \\
\hline Lectin/Gal-2 & 6 & 2 & 1 & 1 & 9 & 1 & 0 & 2 & 5 & 20.7 & $0.15 \pm 0.05$ \\
\hline Lectin/pEA207 & 3 & 4 & $i$ & 2 & 6 & 2 & 0 & 2 & 5 & 8.3 & $0.17 \pm 0.08$ \\
\hline pEA207/Aat-m & 0 & 5 & 0 & 5 & 5 & 2 & 1 & 3 & 4 & 9.7 & $0.40 \pm 0.09$ \\
\hline pEA207/Gal-2 & 2 & 3 & 0 & 4 & 7 & 1 & 1 & 2 & 5 & 9.7 & $0.28 \pm 0.08$ \\
\hline
\end{tabular}

${ }^{a}$ Genotype designations: $\mathrm{j}=$ homozygous JII 794; $\mathrm{h}$ = heterozygous; $\mathrm{s}=$ homozygous Slow.

group 7 but also strongly confirmed the location of the lectin gene.

\section{Discussion}

Four sequences homologous to pPS15-50 have been reported in the pea genome (Kaminski et al. 1987). Our results also identify four EcoRI fragments in J11794 hybridizing to the pea lectin cDNA and three fragments in Slow. The coding region of the pea lectin gene lacks an EcoRI site as well as introns (Higgins et al. 1983; Kaminski et al. 1987). Hence, these fragments apparently are distinct copies of the lectin sequence or pseudogenes with abbreviated or modified sequences. Our results demonstrate that these sequences are clustered on linkage group 7 near Gal-2.

The small number of inbred lines examined limits our ability to estimate the

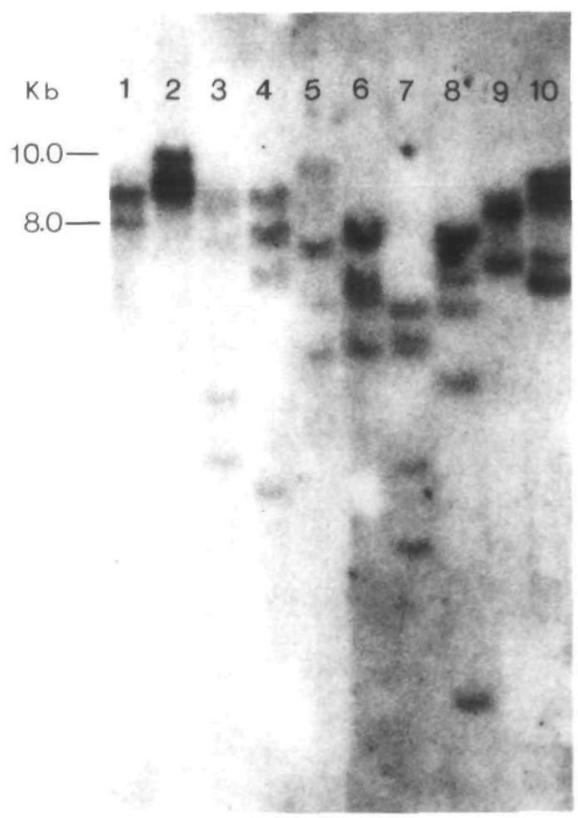

Flgure 2. Polymorphisms between the parents J11794 (lanes 1, 3, 5, 7, and 9) and "Slow" (lanes 2, 4, 6, 8, and 10) after their genomic DNA was digested with different restriction enzymes (same order as in Figure IA) and hybridized with labeled lectin-like cDNA pEA207. tightness of the lectin cluster. However, genetic linkage of the multigene family of the Phaseolus seed lectins has been reported (Brown et al. 1981; Hoffman and Donaldson 1985). In addition, proteins such as ribulose bisphosphate carboxylase, actin, and leghemoglobin are coded by small families of genes, and usually at least a portion of the genes within the family is tightly linked. These clusters segre-

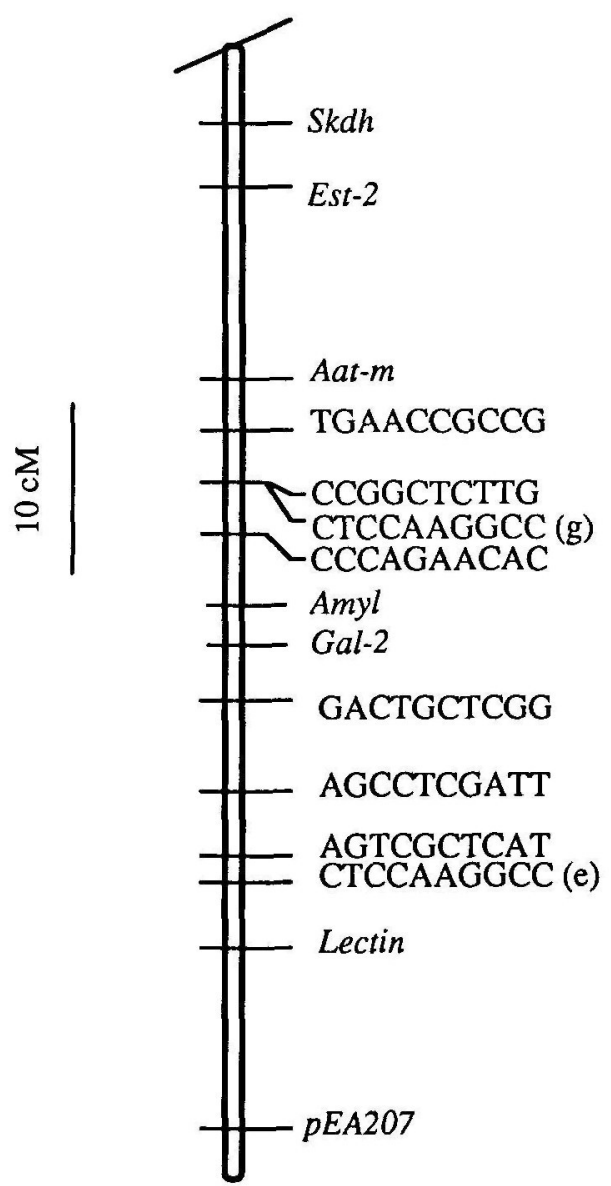

Figure 3. A portion of linkage group 7, showing the positions of the lectin genes and the lectin-like cDNA clone pEA207 relative to five isozyme loci and eight RAPD markers. Skdh is toward the centromere, while pEA 207 is at the distal end of the chromosome. The positions of the RAPD markers are labeled by the sequence of the oligonucleotide primer generating the polymorphism.

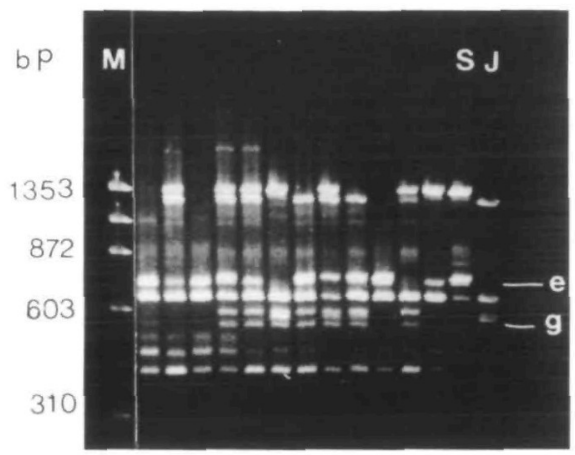

Figure 4. RAPD products generated using primer sequence 5 '-CTCCAAGGCC. Seven polymorphisms seg regated in the recombinant inbred lines produced from J11794 (J) $\times$ Slow (S). Two of these, marked "e" and "g," mapped on linkage group 7 (see Figure 3). M = DNA size standard.

gate as single Mendelian units in $\mathrm{F}_{2}$ and later generations.

Our results suggest that the cDNA clone, pEA207, also may be a representative of a tightly linked multigene family. The clone was mapped to the same linkage group as the lectin genes but slightly further away from Gal-2. The transcript of this clone shows $37 \%$ homology to a 75 -amino acid overlap of the pea major seed lectin gene encoded by pPS15-50, and Dobres and Thompson (1989) suggested that pEA207 encodes a polypeptide with lectin-like function.

The placement of the lectin genes on linkage group 7 suggests that the altered Rhizobium strain-specificity displayed by several sym mutants is not a direct consequence of a mutation in the lectin coding sequence. Mutations at sym2 all display linkage with markers on linkage group 1 (Weeden et al. 1990; Young 1985). Preliminary data place sym18near sym2 (Weeden et al. 1990), and Sym22 is linked to markers on linkage group 2 (Temnyk, Weeden, Lu, and LaRue, unpublished observations). The only sym gene mapped near the lectin gene cluster is syml 5 (Weeden et al. 1990). The phenotype of sym 15 is short lateral roots and few or no nodules with all strains of Rhizobium tested. Thus the syntenic relationships between the lectin gene and sym 15 is probably coincidental rather than functional. We conclude that none of the known sym genes involves a mutation of the lectin genes.

\section{References}

Bauchrowitz MA, Barkers DG, Nadaud I, Rouge P, and Lescure B, 1992. Lectin genes from the legume Medicago truncatula. Plant Mol Biol 19:1011-1017.

Borrebaeck CAK, 1984. Detection and characterization of a lectin from non-seed tissue of Phaseolus vulgaris. Planta 161:223-228 
Brown JWS, Bliss FA, and Hall TC, 1981. Linkage relationships between genes controlling seed proteins in French Bean. Theor Appl Genet 60:251-259.

Buffard D, Kaminski PA, and Strosberg AD, 1988. Lectin-gene expression in pea (Pisum sativum L.) roots. Planta 173:367-372.

Díaz CL, Lems-Van Kan P, Van Der Schaal IAM, and Kijne JW, 1984. Determination of pea (Pisum sativum L.) root lectin using an enzyme-linked immunoassay. Planta 161:302-307.

Díaz CL, Melchers LS, Hooykaas PJJ, Lugtenberg BJJ, and Kijne JW, 1989. Root lectin as a determinant of host-plant specificity in the Rhizobium-legume symbiosis. Nature 338:579-581.

Dobres $\mathrm{M}$ and Thompson W, 1989. A developmentally regulated bud specific transcript in pea has sequence similarity to seed lectins. Plant Physiol 89:833-838.

Doyle JJ and Doyle JL, 1987. A rapid DNA isolation procedure for small quantities of fresh leaf tissue. Phytochem Bull 19:11-15.

Etzler M, 1986. Distribution and function of plant lectins. In: The lectins, properties, function and application in biology and medicine (Liener IE, Sharon $N$, and Goldstein IJ, eds). Orlando/New York: Academic Press; 393-397.

Feinberg AP and Vogelstein B, 1983. A technique for labeling restriction endonuclease fragments to highspecific activity. Anal Biochem 132:6-13.

Foriers A, Lebrun E, Van Rappenbusch R, de Neve $R$, and Strosberg AD, 1981. The structure of the lentil (Lens culinaris) lectin. J Biol Chem 256:5550-5560.

Gatehouse JA and Boulter D, 1980. Isolation and properties of a lectin from the roots of Pisum sativum (garden pea). Physiol Plant 49:437-442.
Heslop-Harrison Y, 1976. Location of concanavalin Abinding sites on the stigma surface of a grass species. Micron 7:33-36.

Higgins TJV, Chandler PM, Zurawski G, Button SC, and Spencer D, 1983. The biosynthesis and primary structure of pea seed lectin. J Biol Chem 258:9544-9549.

Hoffman LM and Donaldson DD, 1985. Characterization of two Phaseolus vulgaris phytohemagglutinin genes closely linked on the chromosome. EMBO J 4:883-889.

Kaminski PA, Buffard D, and Strosberg AD, 1986. Detection of lectin-related sequences in the genome of Sesbania rostrata. Plant Sci 46:111-116.

Kaminski PA, Buffard D, and Strosberg AD, 1987. The pea lectin gene family contains only one functional gene. Plant Mol Biol 9:497-507.

Kneen BE, vam Vikites D, and LaRue TA, 1987. Induced symbiosis mutants of Pisum sativum. In: Molecular genetics of plant-microbe interaction. (Verma DPS and Brisson N, eds). Dordrecht: Martinus Nijhoff; 79-84.

Knox RB, Clarke AE, Harrison S, Smith P, and Marchalonis JJ, 1976. Cell recognition in plants: determination of the stigma surface and their pollen interactions. Proc Natl Acad Sci USA 73:2788-2792.

Lander ES, Green P, Abrahamson J, Barlow A, Daly MJ, Lincoln SE, and Newburg L, 1987. Mapmaker: an interactive computer package for constructing primary genetic linkage maps of experimental and natural population. Genomic 1:174-181.

Okamura JK, Jofuku KD, and Goldberg RB, 1986. Soybean seed lectin gene and flanking non seed protein genes are developmentally regulated in transformed tobacco plants. Proc Natl Acad Sci USA 83:8240-8244.
Reed KC and Mann DA, 1985. Rapid transfer of DNA from agarose gels to nylon membranes. Nucleic Acids Res 13:7207-7221

Suiter KA, Wendel JF, and Case JS, 1983. LINKAGE-1: a PASCAL computer program for the detection and analysis of genetic linkage. J Hered 74:203-204.

Torres AM, Weeden NF, and Martin A, 1993. Linkage among isozyme, RFLP and RAPD markers in Vicia faba Theor Appl Genet 85:937-945.

Vodkin LO and Raikhel NV, 1986. Soybean lectin and related proteins in seeds and roots of $\mathrm{le}^{+}$and $\mathrm{le}^{-}$soy bean varieties. Plant Physiol 81:558-565.

Vodkin LO, Rhodes PR, and Goldberg RB, 1983. A lectin gene has the structural features of a transposable el ement. Cell 34:1023-1031.

Weeden NF, Kneen BE, and LaRue TA, 1990. Genetic analysis of sym genes and other nodule-related genes in Pisum sativum. In: Nitrogen fixation: achievements and objectives (Gresshoff PM, Roth LE, Stacey G, and Newton WE, eds). New York: Chapman and Hall; 323330 .

Weeden NF and Wolko B, 1990. Linkage map of garden pea (Pisum sativum) based on molecular markers. In Genetic maps, book 6 (O'Brien SJ, ed). Cold Spring Harbor, NY: Cold Spring Harbor Laboratory Press; 106112

Young JPW, 1985. Linkage of sym-2, the symbiotic specificity locus of Pisum sativum. J Hered 76:207-208. 